\title{
Politics and Poverty: Counting the costs
}

\author{
Oliver Mtapuri \\ University of Limpopo \\ Edupark, P.O. Box 756, Fauna Park 0787, Polokwane \\ Email: simbaomtapuri@yahoo.com
}

Doi:10.5901/mjss.2014.v5n8p610

\begin{abstract}
This paper offers an entrée into the discussion with the argument that politics have a cost in development - these costs can be political, economic, social or even emotional, as well as psychological. To this end, the paper attempts to locate the intersection between politics and poverty and poses the question: "Do politics matter?" This paper is based on a desk-top study and used mainly secondary data. The paper has theoretical significance as it unmasks the role that politics play in the poverty discourse. This paper falls within the broad theme: Public policies and politics. In particular, it posits a framework for understanding the link between politics and poverty. The framework is this paper's major contribution.
\end{abstract}

Keywords: politics, poverty, corruption, public policy

\section{Introduction}

This paper examines the impact of politics in either deepening poverty or alleviating it. For instance, in the African context, anecdotal evidence suggests that a system of political patronage exists in which only card-carrying members of specific political (especially ruling) parties receive service while non-members do not. This is also borne out by the number of service delivery protests. In the context of South Africa, a Sunday Times editorial (5 August 2012, page 4, Review), noted that according to a TNS SA Survey, $56 \%$ of 2,000 urban adults said they were unhappy with the service they receive from municipalities. Meanwhile, government ministers, MECs and other officials blame these protests on "politics" and "jostling for positions" in municipalities. "Unless corruption, maladministration and incompetence are rooted out", municipalities will not be able to deliver proper services to citizens (Sunday Times editorial, 5 August 2012).

Pottie (2003: 141) contends that the African National Congress (ANC) government has adopted contradictory policies by simultaneously pledging to provide universal access to services (against a backdrop of high levels of inequality and poverty, unemployment and skewed access to services) and fiscal sustainability against a backdrop of weak institutional capacity in the provinces and local municipalities. Political connections and networks have been used to award tenders to a select few, resulting in shoddy service delivery at the hands of service providers. A case in point has been the construction of Reconstruction and Development Programme (RDP) houses that are of poor quality (RDP houses are low-cost houses built by the government for the poor) (Pottie, 2003: 141).

Because politicians make policies, the installation of huge Cabinets in countries means that funds meant to develop communities may be deployed to feed the 'gravy train' and keep a bloated state machinery running. There have been numerous reports of misuse of state resources by cabinet ministers, e.g., through inflated hotel bookings including bookings for non-civil servants within their entourages; and the misuse of credit cards. This money could have been used to benefit society. Robinson (2005: 31) surmises to say that management therefore is a political activity in which managers 'have to use situations to advance their own function's interests' and he further cites a Harvard Business Review article which stated that:

Leadership is not a moral concept and that leaders are not necessarily good people; they are like everyone else, 'trustworthy and deceifful, cowardly and brave, greedy and generous' Robinson (2005: 31).

Within the context of a systems approach, Ulrich (2004: 206) notes that "Churchman accepted that the meaning and merit of ends could only be understood by identifying their whole-systems implications" and therefore a system implies "interconnected complex of functionally related components" (Churchman et al., 1957: 7 cited in Ulrich 2004: 211). In this case Churchman is urging the study of a system as a whole. Ulrich (1998: 1) claims that "competent managers will need to be competent citizens in the first place!' The dearth in the application of management principles 
and the lack competences result in mismanagement of both public and private entities.

\section{Materials and Methods}

This paper is based on a desk-top study and used mainly secondary data. To that end, literature on corruption and its impacts on poverty was extensively reviewed.

\subsection{Do politics matter?}

It can be argued that the decision by any government to deploy the biggest share of its budget to weapons, health, education, or science and technology, is a political decision. Whether expenditure on weapons serves as an investment in defence or sheer wasteful expenditure in the absence of a threat of war is a matter for debate. Expenditure on health and education as well as science and technology can be considered investment in human capital formation and development in general. The allocation of budgets is an issue that preoccupies all countries at all stages of their development. Unsworth (2009: 884) notes that development challenges are equally political and are therefore not merely financial and technical and as such she criticizes aid donors for focusing on [development] policy and practice without a clear understanding of the political processes involved in that development. Segal's (2008, cited in Unsworth, 2009: 887) study of Nepal observed that the persistence of poverty was not necessarily "due to lack of government capacity, which could be addressed by strengthening public institutions and stimulating demand from poor people for improved services, instead it was the actions and behaviour of the elite-dominated government, bureaucracy and aid donors as intrinsically part of the problem". In unpacking the intersections and transections between politics and poverty, it is necessary to debunk and discredit the notion of packaged 'one-size-fits-all' development solutions, particularly poverty alleviation interventions, in developing countries, principally because these countries have different socio-economic, political and historical trajectories. To this end, Unsworth, (2009: 887) proposes that it is imperative for development practitioners to engage in political analysis in order to fine-tune their expectations, and re-arrange their priorities and project design as well as implementation modalities in light of the political landscape. Political analysis allows partners to find areas of common interest to engage and shape the design of the strategies and tactics to be used, including the adoption of appropriate approaches to development.

\subsection{Tensions between politics and poverty: Corruption}

The impact of corruption cannot be ignored in the poverty discourse. Politics seem to obscure poverty. Svensson, (2005:20) defines public corruption as "the misuse of public office for private gain"; Jain, (2001, cited in Aidt, 2003:F632) supports that view, claiming that "corruption is an act in which the power of public office is used for personal gain in a manner that contravenes the rules of the game". Punch (2000: 302) defines corruption as a broad range of deviant activity although traditionally associated with bribery (or 'graft') or accepting a non-financial reward or promise of a reward); and 'for doing or not doing something that is clearly against your duty' or a reward for the performance of an illicit 'service'.

According to Nye (1967:419) corruption includes bribery "(use of a reward to pervert the judgment of a person in a position of trust); nepotism (bestowal of patronage by reason of ascriptive relationship rather than merit); and misappropriation (illegal appropriation of public resources for private use)". Aidt (2003: F635) contends that "whenever authority is delegated to a bureaucracy, the potential for corruption is created". This seems to insinuate that where there is an authority, which necessarily has to diffuse its power as do all government institutions as well as the private and nongovernmental sectors, there is bound to be corruption.

To support this claim Aidt (2003: F633) contends that there are three conditions which are necessary for corruption to take place, namely, 1. Discretionary power: in which the dispenser of policy can exercise his/her discretion. 2. Economic rents: the dispenser must be able to create rents which can be extracted or exploit existing ones. 3. Weak institutions: which allow the dispenser "to exploit their discretionary power to extract or create rents". This implies that to curb corruption, it is necessary to usurp all discretionary powers, close all loopholes that create extractable rents and strengthen institutions. Svensson, (2005:20) argues that corruption is "a reflection of a country's legal, economic, cultural and political institutions" and that political development denotes "rational, modern, honest government...[which] cannot coexist with corruption in the same time period; and if corruption is endemic in government, a politically developed society cannot exist" (Nye, 1967:418).

While some perceive the benefits of corruption, others argue against it. Nye (1967:417) is of the view that the 
establishment of the British cabinet system in the 18th century and the integration of immigrants in America in the 19th century were the result of corruption. Gluckman as cited by Nye (1967) argues that scandals linked to corruption tend to strengthen the value system as a whole and "humanizes government" (Nye 1967: 420). Similarly, Aidt (2003: F633) argues that corruption can enhance efficiency as it allows people to circumvent "misguided government policies and red tape, [which] is viewed as a rational market response to pre-existing government failures".

The disadvantages of corruption include wasted resources; capital outflow into Swiss Banks; investment distortions as looted funds are invested in easy-to-conceal investments instead of areas of need; loss of investor confidence; political instability; national disintegration; military takeovers; moonlighting by dedicated civil servants as they reduce their effort or even leave the country; and the loss of the legitimacy of the government (Nye 1967: 421). Svensson, (2005:19) argues that the worst forms of corruption include outright theft of public funds and the damage caused by companies and people who pay bribes to circumvent health and safety regulations meant to protect the public.

\subsection{Counting the costs}

Millions of dollars are lost through corruption. Svensson, (2005:31) however, argues that the literature on the quantification of corruption is still in its infancy. For example, he argues that it ranges from a few percent in the Oil for Food Program in Iraq to 80 percent of the resources meant for a primary education program in Uganda. From 1991-1995, schools in Uganda received only 13 percent of the funds earmarked for them from government; the rest was siphoned out of the system by civil servants and politicians. As much as 80 percent of Ugandan firms reported that they had to pay bribes in order to access government services (Svensson, 2005:31). Government is supposed to provide for the basic needs of the population such as education and create a conducive environment for the private sector to thrive and create jobs.

According to Mhlauli (2011:1354) fraudulent acts were detected in the Eastern Cape Department of Health in South Africa; one service provider had more than a hundred companies on the Department's procurement database and there were "no less than 107 suppliers who had the same bank account number, and 165 suppliers had the same telephone number, while 4496 had the same physical address and 934 the same postal address" (Bateman, 2011, cited in Mhlauli, 2011: 1354). Svensson (2005:38) notes that corruption is one of the key reasons why public spending on growth and social welfare is weak in many countries. Mhlauli (2011:1355) observes that nepotism has also been rife in the same Eastern Cape Department of Health; for example, four senior officials were suspended in 2009 on allegations of misconduct/nepotism. A pharmacist on suspension since 2004, is still enjoying his salary of more than R15 000 per month from the Department. Mhlauli (2011:1355) contends that corruption is therefore a major impediment to service delivery in South Africa because resources are wasted, thereby placing the ruling government under immense pressure. He notes that the consequences of corruption include dissatisfaction and low morale [on the part of committed civil servants] and hostility reflecting a lack of Fayol's 'command and control' and requiring competent managers who are what Ulrich termed 'competent citizens' (Ulrich, 1998: 1).

In the same vein, Mle \& Maclean (2011) note that local government is failing to deliver on its constitutional mandate because of a lack of integrity, ethical conduct and good governance which has resulted in violent service delivery protests by communities. Mle \& Maclean (2011:1372) further contend that political infighting within and between parties, punctuated by patronage and nepotism in many spheres of government, lead to a scramble for state resources and self enrichment rather than representing ideological or policy contestations. According to Moeti, (2007, cited in Mle \& Maclean, 2011:1374), such unethical conduct erodes the public's trust and confidence in the integrity of public office bearers. The net effect is that the people's trust in elected office bearers and government in general diminishes. Furthermore, Sokomani (2005:84) argues that political parties can be used as conduits for criminal and drug money, patronage, vote buying, buying positions on party lists, and the illegal use of public resources - which results in 'who pays the piper calls the tune'. He argues that if left unchecked, this may paralyse democracy and inhibit development. Thus, "The undue influence of money in politics weakens political party organizations by eroding their accountability and transparency" (Sokomani, 2005:86).

Corruption is pervasive. Fisman (2001, cited in Svensson, 2005:38) observes that political networks in Indonesia allow firms to specialize in rent seeking corruption as a means of growth. Similarly, Khwaja and Mian (2004, cited in Svensson, 2005:38) note that the borrowing and default rates of politically connected firms in Pakistan reflect their motive of capturing public resources for personal use. Thus, Svensson (2005:37), concludes that one of the major social losses resulting from corruption is the inefficient allocation of capital, talent, and technology reflecting Machiavellian tendencies. This suggests a misallocation of resources to less productive areas to the detriment of development. It is fairly obvious that people with the authority to influence important decisions are potential targets for corrupters (Punch, 2000: 302). To 
prevent corruption, Punch (2000) suggests clean-up campaign, strong leadership, adoption of a proactive strategy, holding leaders responsible, the pursuit of suspects through disciplinary procedures, criminal prosecutions including early retirements and strong reassurances to those who are doing good.

\section{Results and Discussion}

\subsection{Politics and poverty: towards a framework}

Using game theory, Naudé (2003:36) claims that poverty and inequality "can be understood as the outcome of a repeated game in which the players are caught in a poverty equilibrium, or 'Prisoners' Dilemma"'. He argues that for the players to unlock the dilemma it is necessary to for them to co-operate, with mediation and co-ordination from "appropriately designed institutions". Such institutions may include "an open, democratic society with a free press and watchdog organizations, an independent judiciary, enforceable property rights and contracts that human rights can flourish, and that people can progressively achieve their entitlements" (Naude, 2003:37). Naude (2003:37) further argues that "good citizenship is essential to poverty eradication.... good citizenship may be dependent on culture, and culture will depend on the norms (shared values) of a society". For Mubangizi (2005:38) policies and institutions for poverty reduction should be steeped in the norms and values contained in the international law of human rights. While it has been argued that there is a need for 'appropriate institutions' and the adoption of the human rights approach to development, what is lacking is the content and essence of how these new organizations can be established in terms of process and how they should take into account cultural and gender diversity and other considerations. Naudé (2003:49) adds that in order to change institutions, it is imperative for society to change "its habits and thoughts, including its cultural paradigms or worldviews". This is a mammoth task at local level, let alone on a global scale. However, Narayan (1999, cited in Naudé, 2003:54) notes that norms and values are critical for the creation of social cohesion, solidarity and social capital within previously disparate groups.

Unsworth (2009: 886) contends that "while the implicit assumption is still that the obstacles to better governance and development performance are primarily financial, technical and managerial, and that progress can be made through more appropriate policies, capacity building, strengthening demand from civil society and dialogue or conditionality to change the behaviour of key individuals", there remains a need to understand the politics.

Unsworth (2009) identifies three barriers to politics, namely, intellectual barriers, maintenance of the status quo and lack of local ownership. I transformed the barriers posited by Unsworth (2009) to opportunities as shown in Table 1 below.

Table 1: Barriers and Opportunities to Politics

\begin{tabular}{|l|l|}
\hline Barriers to politics by Unsworth (2009: 887) & Opportunities (by Author) \\
\hline $\begin{array}{l}\text { 1. Intellectual barriers: people must change } \\
\text { their existing mental models of development } \\
\text { (organizational culture and management } \\
\text { arrangements). }\end{array}$ & $\begin{array}{l}\text { Involve political scientists and not just economists and technical advisers in } \\
\text { development. Interrogate current mental models and embrace new ones with } \\
\text { respect to new organizations, organizational cultures and management } \\
\text { arrangements. }\end{array}$ \\
\hline $\begin{array}{l}\text { 2. NGOs have institutional incentives to } \\
\text { maintain the status quo. }\end{array}$ & $\begin{array}{l}\text { Debunk the notion of the maintenance of the status quo in the NGO sector as } \\
\text { regressive and explore new territory. }\end{array}$ \\
\hline $\begin{array}{l}\text { 3. No local ownership if direct operational } \\
\text { solutions are not offered. }\end{array}$ & Offer direct operational solutions to gain local ownership. \\
\hline & Understand the local formal and informal political dynamics in a given context. \\
\hline & Understand the political, economic, social and cultural history of a given context. \\
\hline
\end{tabular}

There have been positive changes in development discourse and practice in the past few years regarding issues of conditionality and the exploration of new forms thereof; from 'government first' approaches to alternatives, the acceptance that change is incremental and needs to be locally driven, the appreciation that donor behavior can be detrimental to projects and the adoption of a systems approach to the 'whole of government' that connects issues of development with security, business, corruption and diplomacy at both the local and international levels (Unsworth, 2009: 885). Unsworth $(2009: 884)$ concludes by observing that, "politics is central to development". To establish this centrality, the next section assesses the impact of corruption.

The social effects of corruption, in this case, bribery and nepotism, could include protests and loss of legitimacy, including popular resistance. The costs could include the destruction of property which is quantifiable in monetary terms. 
Table 2 presents the political costs of some dimensions of development.

Table 2: Political costs

\begin{tabular}{|c|c|c|}
\hline Dimension & Effects & Costs \\
\hline Social & $\begin{array}{l}\text { Protests } \\
\text { Loss of legitimacy } \\
\text { Resistance Insurgency }\end{array}$ & Destruction of property \\
\hline Economic & $\begin{array}{l}\text { Diversion of funds } \\
\text { Empty coffers }\end{array}$ & Loss of investor confidence \\
\hline Political & $\begin{array}{l}\text { People join other parties } \\
\text { (especially the opposition) }\end{array}$ & $\begin{array}{l}\text { Loss in elections } \\
\text { Mistrust of institutions of governance } \\
\text { Threats to national sovereignty }\end{array}$ \\
\hline Environmental & $\begin{array}{l}\text { Degradation } \\
\text { Pollution }\end{array}$ & \\
\hline Psychological & $\begin{array}{l}\text { Disillusionment } \\
\text { Hardening of feelings }\end{array}$ & Unengaged citizenry \\
\hline Emotional & Hatred of others e.g. elite & Loss of cohesion \\
\hline
\end{tabular}

This paper posits a framework within which to understand the interplay between politics and poverty (see Figure 1 below). Good citizenship which incorporates culture, beliefs, practices, solidarity and cohesion must be part of the equation to eradicate poverty. The economic conditions or situation will have to be taken into account, including human rights and shifts in paradigms. Appropriate institutions (the politics) would need to be conceived in line with what Malatii and Mtapuri (2012) propose - a new Social Learning and Change (SLC) organization.

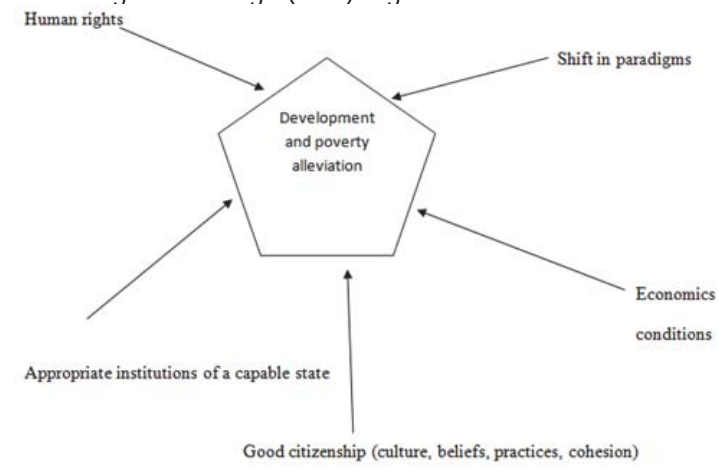

Fig 1: Framework of the interplay between politics and development (poverty)

According to Malatji \& Mtapuri (2012) argue that the new organization could take the form of a new CBO - a Social Learning and Change initiative, composed of many players - economists, civil servants, business people, development practitioners, political scientists and others. This heralds the creation of a civic corporation/civic NGO/civic government based on the premise that 'either we collaborate or we perish'.

\section{Conclusion}

This paper has argued that politics do matter in the poverty discourse and development practice. It also argued for the creation of a new organization. The paper unpacked some of the costs and benefits of corruption and noted that political analysis is not an option but is imperative for development. This resonates with Unsworth (2009: 887) who argues that "politics is not just an obstacle to be overcome, but an integral part of the search for a way forward". On the basis of this premise and in light of the foregoing, politics do matter in the poverty discourse. It is also critical in attempts to improve the human conditions to consider Ulrich's words that 'the search for a rational approach to improvement implies a continuous search for comprehensiveness, through a never-ending process of learning more and more about the world' (Ulrich, 2004: 205) . 


\section{References}

Aidt, T. 2003. Economic Analysis of Corruption: A Survey Review, The Economic Journal, 113 (491): F623-652).

Koelble, A.T. \& LiPuma, E. 2010. Institutional obstacles to service delivery in South Africa, Social Dynamics, Journal of African Studies, 36(3): 565-589.

Malatji, M.I. \& Mtapuri, O. 2012. Poverty alleviation: Do Community Based Tourism Enterprises make a difference, Tourism Review International, 16(1): 21 - 40.

Mhlauli, N. 2011. Maladministration, corruption and financial misconduct in the Eastern Cape Department of Health, Journal of Public Administration, 46 (4): 1351- 1363.

Mle, T.R. \& Maclean, S. 2011. Ethics, integrity and good governance: The Case of South Africa's Local Sphere of Government, Journal of Public Administration, 46 (4): 1364 - 1383.

Mubangizi, J. 2005. Know your rights: Exploring the connections between Human rights and poverty reduction with specific reference to South Africa, South African Journal of Human Rights, 21: 32-46.

Naudé, W. 2003. Poverty eradication: the need for good citizenship, Acta Academica, 35(2): 35-61.

Nye, J. 1967. Corruption and Political Development: A Cost-Benefit Analysis, The American Political Science Review, 61 (2): $417-427$.

Pottie, D. 2003. Housing the nation: the politics of low-cost housing policy in South Africa since 1994, Politeia, 22 (1): 119-143.

Punch, M. 2000. Police corruption and its prevention, European Journal on Criminal Policy and Research, 8: 301-324.

Robinson, D. 2005. Management Theorists: Thinkers for the $21^{\text {st }}$ century? Training Journal, available at www.trainingjournal.com /products/backissues.jsp accessed 11 February 2013.

Sokomani, A. 2005. Money in Southern African politics: The party funding challenge in Southern Africa, African Security Review, 14(4): 81-90.

Svensson, J. 2005. Eight Questions about Corruption, Journal of Economic Perspectives, Vol. 19 (3): 19-42.

Ulrich, W. 1998. Systems Thinking as if People Mattered: Critical Systems Thinking for Citizens and Managers, Working Paper No. 23, Lincoln School of Management, University of Lincolnshire \& Humberside (now University of Lincoln), Lincoln, UK.

Ulrich, W. 2004. In memory of C. West Churchman (1913-2004) Reminiscences, retrospectives, and reflections, Journal of Organizational Transformation and Social Change, Vol. 1, No. 2-3: 199-219.

Unsworth, S. 2009. What's politics got to do with it? Why donors find it so hard to come to terms with politics, and why this matters, Journal of International Development, 21: 883-894. 